\title{
TRADISI MERARI' SUKU SASAK DI LOMBOK DALAM PERSPEKTIF HUKUM ISLAM
}

\author{
Bustami Saladin \\ (Program Pascasarjana UIN Sunan Ampel Surabaya \\ JL. A. Yani 117 Surabaya, email:bustamisaladin@yahoo.co.id)
}

\begin{abstract}
Abstrak
Perkawinan adalah ikatan lahir batin antara seorang pria dengan seorang wanita sebagai suami istri untuk membentuk keluarga yang bahagia dan kekal berdasarkan Ketuhanan Yang Maha Esa. Ikatan perkawinan merupakan ikatan suci yang berdasarkan nilai-nilai ketuhanan untuk membentuk keluarga sakinah, mawaddah dan rahmah. Salah satu adat yang dipegang teguh oleh masyarakat Lombok adalah kawin lari. Dalam adat Sasak pernikahan dengan cara kawin lari ini lebih populer disebut dengan merari'. Oleh karena itu, Merari' dalam bahasa Indonesia disebut dengan istilah kawin lari. Secara terminologis, merari' mengandung dua arti. Pertama, lari atau melarikan. Ini adalah arti yang sebenarnya. Kedua, keseluruhan pelaksanaan perkawinan menurut adat Sasak. Bagi masyarkat Sasak, merari' berarti mempertahankan harga diri dan menggambarkan sikap kejantanan seorang pria Sasak, karena ia berhasil mengambil (melarikan) seorang gadis pujaan hatinya. Meskipun metode kawin lari ini tidak pernah dijelaskan di dalam nash (al-Qur'an dan Hadits), tetapi bila ditinjau dari perspektif maqâshid al-syarî'ah, maka stutus hukum pernikahan dengan metode kawin lari ini tetap sah. Karena dalam kelangsungan akad nikahnya tetap memenuhi syarat dan rukun sebagaimana yang telah disyari'atkan Islam.
\end{abstract}

\begin{abstract}
A marriage is the union between a man and a woman as a couple to form a happy and eternal family based on the one and only God. A marriage is a holy union based on the divinity values to form a sakinah, mawaddah and rahmah family. One of customs held firmly by Lombok society is elopement. In Sasak custom of marriage by eloping is more popular called merari'. Therefore, in Indonesian language merari' is called with the term of kawin lari (elopment). In terminology, merari' contains two meanings. First, it is running or run off. It is the real
\end{abstract}


meaning. Second, the whole marriage implementation based on Sasak custom. For Sasak society, merari' is keeping self-esteem and describing manhood of a Sasak man, because he has succeeded in eloping his beloved girl. Although, this elopment method is never explained in nash (Qur'an and Hadits), but if it is viewed from maqâshid al-syarîah (the purposes of Islamic law), the status of marriage law with this elopment method is legal. It is because in the marriage ceremony has filled the requirements and pillars as it has been instructed by Islam.

\section{Kata-kata Kunci \\ Merari', kawin lari, suku Sasak, Lombok, hukum Islam}

\section{Pendahuluan}

Manusia merupakan makluk sosial (zoonpoliticoon), sehingga tidak bisa hidup tanpa adanya manusia lainnya. Sejak lahir manusia telah dilengkapi dengan naluri untuk hidup bersama dengan orang lain. Naluri untuk hidup bersama dengan orang lain mengakibatkan hasrat yang kuat untuk hidup teratur. ${ }^{1}$ Demikian pula diantara wanita dan pria itu saling membutuhkan, saling mengisi, saling berkaitan, tidak bisa dilepaskan antara satu dengan yang lainnya. Dan rasanya tidak sempurna hidupnya seorang wanita tanpa didampingi seorang pria sekalipun dia beralaskan emas dan permata, demikian sebaliknya tidak akan sempurna hidup seorang pria tanpa kehadiran wanita sebagai pelengkapnya. Perkawinan ialah ikatan lahir batin antara seorang pria dengan seorang wanita sebagai suami istri untuk membentuk keluarga yang bahagia dan kekal berdasarkan Ketuhanan Yang Maha Esa. Ikatan lahir adalah hubungan formal yang dapat dilihat karena dibentuk menurut undang-undang, yang mengikat kedua pihak dan pihak lain dalam masyarakat. Sedangkan ikatan batin adalah hubungan tidak formal yang dibentuk dengan kemauan bersama yang sungguh-sungguh mengikat kedua pihak. Ikatan perkawinan merupakan ikatan suci yang berdasarkan nilai-nilai ketuhanan untuk membentuk keluarga sakinah, mawaddah, dan rahmah. Ikatan perkawinan bukan saja ikatan perdata, tetapi ikatan lahir batin antara seorang suami dengan seorang isteri. Perkawinan tidak lagi hanya sebagai hubungan jasmani, tetapi juga merupakan

\footnotetext{
1 Soejono Soekanto, Pokok-Pokok Sosiologi Hukum (CV Rajawali: Jakarta:1982), hlm. 9
} 
hubungan batin. Pergeseran ini mengesankan perkawinan selama ini hanya sebatas ikatan jasmani ternyata juga mengandung aspek yang lebih subtantif dan berdimensi jangka panjang. Ikatan yang didasarkan pada hubungan jasmani itu berdampak pada masa yang pendek, sedangkan ikatan lahir batin itu lebih jauh. Dimensi masa dalam ini dieksplisitkan dengan tujuan sebuah perkawinan yakni untuk membangun sebuah keluarga bahagia dan kekal berdasarkan Ketuhanan Yang Maha Esa. ${ }^{2}$ Hukum perkawinan merupakan bagian integral dari syarî'ah, yang tidak terpisahkan dari dimensi akidah dan akhlak Islami. Di atas dasar inilah, hukum perkawinan ingin mewujudkan perkawinan di kalangan orang Muslim menjadi perkawinan yang bertauhid dan berakhlak, sebab perkawinan semacam inilah yang bisa diharapkan memiliki nilai transedental dan sakral untuk mencapai tujuan perkawinan yang sejalan dengan tujuan syarî'ah. ${ }^{3}$ Ketentuan-ketentuan mengenai perkawinan menurut syarî́ah mengikat kepada setiap Muslim, dan setiap Muslim perlu menyadari bahwa didalam perkawinan terkandung nilai-nilai 'ubudiyah. Karena itu, ikatan perkawinan diistilahkan dalam AlQur`an dengan "mitsâqan ghalîzhan", suatu ikatan yang mengandung nilai 'ubudiyah, maka memerhatikan keabsahannya menjadi hal yang menjadi sangat prinsipil. 4

\section{Sejarah Asal Usul Tradisi Kawin Lari Di Lombok}

Salah satu adat yang dipegang teguh oleh masyarakat Lombok adalah kawin lari. Dalam adat Sasak pernikahan dengan cara kawin lari ini lebih populer disebut dengan merari'. Secara etimologis kata merari' diambil dari kata "lari". Merari'ang berarti melai'ang atau dalam bahasa Indonesia disebut melarikan. ${ }^{5}$

Oleh karena itu, merari' dalam bahasa Indonesia disebut dengan istilah kawin lari. Secara terminologis, merari' mengandung

2 Amir Nuruddin dan Azhari Akmal Tarigan, Hukum Perdata Islam di Indonesia (Jakarta: Kencana Prenada Media Group, 2006), hlm. 46

${ }^{3}$ M. Anshary MK, Hukum Perkawinan di Indonesia (Yogyakarta: Pustaka Pelajar, 2010), hlm. 10

4 Muhammad Harfin Zuhdi, Tradisi Merari': Akulturasi Islam dan Budaya Lokal, http:/ / lombokbaratkab.go.id/tradisi-merari\%E2\%80\%99-akulturasi-islam-danbudaya-lokal.html/, diakses pada 29 April 2012.

${ }^{5}$ Ibid. 
dua arti. Pertama, lari atau melarikan. Ini adalah arti yang sebenarnya. Kedua, keseluruhan pelaksanaan perkawinan menurut adat Sasak. ${ }^{6}$

Berdasarkan referensi dan informasi dari nara sumber tentang sejarah munculnya tradisi kawin lari (merari') di pulau Lombok, paling tidak ada dua pandangan yang mengemuka, yaitu: Pertama, orisinalitas kawin lari. Kawin lari (merari') dianggap sebagai budaya produk lokal dan merupakan adat asli (genuine) dari leluhur masyarakat Sasak yang sudah dipraktikkan oleh masyarakat sebelum datangnya kolonial Bali maupun kolonial Belanda. Hal ini dikuatkan juga oleh H. L. Hasbulloh7 yang mengatakan bahwa merari' itu adalah asli adat Sasak dan merupakan warisan dari para leluhur suku Sasak. Kedua, tradisi merari'. Kawin lari (merari') dianggap sebagai budaya produk impor dan bukan asli dari leluhur masyarakat Sasak serta tidak dipraktikkan masyarakat sebelum datangnya kolonial Bali. Pendapat ini didukung oleh sebagian masyarakat Sasak dan dipelopori oleh tokoh agama. Pada tahun 1955 di Bengkel Lombok Barat, TGH. Saleh Hambali menghapus kawin lari (merari'), karena dianggap sebagai manifestasi Hinduisme Bali dan tidak sesuai dengan Islam.

Bagaimana mungkin tradisi merari' ini bisa dikatakan produk impor dari Bali, sementara beberapa kampung di Lombok seperti perkampungan Sekarbela yang tidak pernah disentuh ataupun dijajah oleh Anak Agung (kolonial Bali) juga memraktikkan budaya merari', bahkan menjadikannya sebuah adat yang sudah dijalankan oleh para leluhur mereka. Ini adalah bukti nyata bahwa merari' merupakan adat asli suku Sasak di pulau Lombok.

Akan tetapi menurut Nieuwenhuyzen, sebagaimana dikutip Tim Depdikbud, banyak adat Sasak yang memiliki persamaan dengan adat suku Bali, tetapi kebiasaan atau adat, khususnya perkawinan Sasak, adalah adat Sasak yang sebenarnya. ${ }^{8}$ Menurut John Ryan Bartholomew, praktik kawin lari dipinjam dari budaya Bali. Analisis antropologis historis yang dilakukan Clifford Geertz dalam bukunya Internal Convention in Bali (1973), Hildred Geertz dalam tulisannya An

\footnotetext{
${ }^{6}$ Wawancara dengan Lulu Akmal, salah seorang tetua adat suku sasak di Lombok Tengah.

8 Tim Departemen Pendidikan dan Kebudayaan, Adat dan Upacara Perkawinan Daerah Nusa Tenggara Barat (Jakarta: Depdikbud, 1995), hlm. 11.
} 
Anthropology of Religion and Magic (1975), dan James Boon dalam bukunya The Anthropological Romance of Bali (1977), seperti dikutip Bartolomew, memperkuat pandangan akulturasi budaya Bali dan Lombok dalam merari'. ${ }^{9}$ Sebagian lagi tokoh Sasak mengatakan bahwa praktik kawin lari di Lombok merupakan pengaruh dari tradisi kasta dalam budaya Hindu Bali. Berdasarkan kedua argumen tentang sejarah kawin lari (merari') di atas, tampak bahwa paham akulturasi merari' memiliki tingkat akurasi lebih valid. Dalam suku Sasak dikenal adanya strata sosial yang disebut triwangsa. Strata sosial ini sudah jelas sama dengan pola Hindu-Bali. Tradisi merari' ini merupakan bagian dari kebudayaan. Kebudayaan dan kehidupan sosial masyarakat Lombok tidak bisa lepas dari dikhotomi kebudayaan nusantara. Ada dua aliran utama yang memengaruhi kebudayaan nusantara, yaitu tradisi kebudayaan Jawa yang dipengaruh oleh filsafat Hindu-Budha dan tradisi kebudayaan Islam. Kedua aliran kebudayaan itu tampak jelas pada kebudayaan orang Lombok. Golongan pertama, di pusat-pusat kota Mataram dan Cakranegara, terdapat masyarakat orang Bali, penganut ajaran Hindu-Bali sebagai sinkretis Hindu-Budha. ${ }^{10}$ Golongan kedua, sebagian besar dari penduduk Lombok, beragama Islam dan perikehidupan serta tatanan sosial budayanya dipengaruhi oleh agama tersebut. Mereka sebagian besar adalah orang Sasak. Merari' sebagai sebuah tradisi yang biasa berlaku pada suku Sasak di Lombok ini memiliki logika tersendiri yang unik. Bagi masyarkat Sasak, merari' berarti memertahankan harga diri dan menggambarkan sikap kejantanan seorang pria Sasak, karena ia berhasil mengambil (melarikan) seorang gadis pujaan hatinya. Sementara pada isi lain, bagi orang tua gadis yang dilarikan juga cenderung enggan, kalau tidak dikatakan gengsi, untuk memberikan anaknya begitu saja jika diminta secara biasa (konvensional), karena mereka beranggapan bahwa anak gadisnya adalah sesuatu yang berharga, jika diminta secara biasa, maka dianggap seperti meminta barang yang tidak berharga. Ada ungkapan yang biasa diucapkan dalam bahasa Sasak:

\footnotetext{
9 John Ryan Bartholemew, Alif Lam Mim: Kearifan Masyarakat Sasak (Yogyakarta: Tiara Wacana, 2001), hlm. 203.

${ }^{10}$ Fath Zakaria, Mozaik Budaya Orang Mataram (Mataram: Yayasan Sumurmas AlHamidy, 1998), hlm. 10-11
} 
Ara'm ngendeng anak manok baen (seperti meminta anak ayam saja). Jadi dalam konteks ini, merari' dipahami sebagai sebuah cara untuk melakukan prosesi pernikahan, di samping cara untuk keluar dari konflik. ${ }^{11}$

\section{Kawin Lari dalam Perspektif Budaya Lokal}

Bedasarkan penelitian M. Nur Yasin, setidaknya ada empat prinsip dasar yang terkandung dalam praktik kawin lari (merari') di pulau Lombok. ${ }^{12}$ Pertama, prestise keluarga perempuan. Kawin lari (merari') dipahami dan diyakini sebagai bentuk kehormatan atas harkat dan martabat keluarga perempuan. Atas dasar keyakinan ini, seorang gadis yang dilarikan sama sekali tidak dianggap sebagai sebuah wanprestasi (pelanggaran sepihak) oleh keluarga lelaki atas keluarga perempuan, tetapi justru dianggap sebagai prestasi keluarga perempuan. Seorang gadis yang dilarikan merasa dianggap memiliki keistimewaan tertentu, sehingga menarik hati lelaki. Ada anggapan yang mengakar kuat dalam struktur memori dan mental masyarakat tertentu di Lombok bahwa dengan dilarikan berarti anak gadisnya memiliki nilai tawar ekonomis yang tinggi. Konsekuensinya, keluarga perempuan merasa terhina. Jika perkawinan gadisnya tidak dengan kawin lari (merari'). Kedua, superioritas lelaki dan inferioritas perempuan. Satu hal yang tak bisa dihindarkan dari sebuah kawin lari (merari') adalah seseorang lelaki tampak sangat kuat, menguasai, dan mampu menjinakkan kondisi sosial psikologis calon istri. Terlepas apakah dilakukan atas dasar suka sama suka dan telah direncanakan sebelumnya maupun belum direncanakan sebelumnya, kawin lari (merari') tetap memberikan legitimasi yang kuat atas superioritas lelaki. Pada sisi lain, ia menggambarkan sikap

\footnotetext{
${ }^{11}$ Keluar dari konflik biasanya dipahami dalam konteks ketika orang tua wanita menghalangi keinginan antara seorang laki-laki dan wanita yang ingin melakukan perkawinan. Wawancara dengan Husni Muaz, dan Idrus Abdullah, dosen Universitas Mataram Mataram, tanggal 17 Maret 2004. Hal senada juga diungkapkan oleh beberapa nara sumber yang penulis wawancarai, seperti Lalu Jalaludin Arzaki, dan Lalu Gde Superman. Lihat Muhammad Harfin Zuhdi, Parokilaitas Adat Islam Wetu Telu dalam Prosedur Perkawinan di Bayan Lombok (Tesis Program Pascasarjana UIN Jakarta, 2004)

${ }^{12}$ M. Nur Yasin, “Kontekstualisasi Doktrin Tradisional Di Tengah Modernisasi Hukum Nasional: Studi tentang Kawin Lari (Merari') di Pulau Lombok", Jurnal Istinbath, no. I vol. IV (Desember 2006), hlm. 73-75.
} 
inferioritas, yakni ketidakberdayaan kaum perempuan atas segala tindakan yang dialaminya. Kesemarakan kawin lari (merari') memperoleh kontribusi yang besar dari sikap sikap yang muncul dari kaum perempuan berupa rasa pasrah atau, bahkan menikmati suasana inferioritas tersebut Ketiga, egalitarianisme. Terjadinya kawin lari (merari') menimbulkan rasa kebersamaan (egalitarian) di kalangan seluruh keluarga perempuan. Tidak hanya bapak, ibu, kakak, dan adik sang gadis, tetapi paman, bibi, dan seluruh sanak saudara dan handai taulan ikut terdorong sentimen keluarganya untuk ikut menuntaskan keberlanjutan kawin lari (merari'). Kebersamaan melibatkan komunitas besar masyarakat di lingkungan setempat. Proses penuntasan kawin lari (merari') tidak selalu berakhir dengan dilakukannya pernikahan, melainkan adakalanya berakhir dengan tidak terjadi pernikahan, karena tidak ada kesepakatan antara pihak keluarga calon suami dengan keluarga calon istri. Berbagai ritual, seperti mesejah, mbaitwah, sorongserah, dan sebagainya merupakan bukti konkret kuatnya kebersamaan di antara keluarga dan komponen masyarakat. Keempat, komersial. Terjadinya kawin lari hampir selalu berlanjut ke proses tawar menawar pisuke. Proses negoisasi berkaitan dengan besaran pisuke yang biasanya dilakukan dalam acara mbait wali sangat kental dengan nuansa bisnis. Apa pun alasannya, pertimbangan-pertimbangan dari aspek ekonomi yang paling kuat dan dominan sepanjang acara mbait wali. Ada indikasi kuat bahwa keluarga tersebut merasa telah membesarkan anak gadisnya sejak kecil hingga dewasa. Untuk semua usaha tersebut telah menghabiskan dana yang tidak sedikit. Sebagai akibatnya, muncul sikap dari orang tua yang ingin agar biaya membesarkan anak gadisnya tersebut memperoleh ganti dari calon menantunya. Semakin tinggi tingkat pendidikan dan tingkat sosial anak dan orang tua semakin tinggi pula nilai tawar sang gadis. Sebaliknya, semakin rendah tingkat sosial dan tingkat pendidikan anak serta orang tua semakin rendah pula nilai ekonomis yang ditawarkan. Komersialisasi kawin lari tampak kuat dan tertuntut untuk selalu dilaksanakan apabila suami istri yang menikah sama sama berasal dari suku Sasak. Jika salah satu di antara calon suami istri berasal dari luar suku Sasak, ada kecenderungan bahwa tuntutan dilaksanakannya komersialisasi agak melemah. Hal ini terjadi karena ternyata ada dialog peradaban, adat, dan budaya antara nilai nilai yang dipegangi masyarakat Sasak 
dengan nilai nilai yang dipegangi oleh masyarakat luar Sasak. Kontak dialogis budaya dan peradaban yang kemudian menghasilkan kompromi tersebut sama sekali tidak menggambarkan inferioritas budaya Sasak, tetapi justru sebaliknya, budaya dan peradaban Sasak memiliki kesiapan untuk berdampingan dengan budaya dan peradaban luar Sasak. Sikap ini menunjukkan adanya keterbukaan masyarakat Sasak bahwa mulai kebaikan dan kebenaran dari manapun asal dan datangnya bisa dipahami dan bahkan diimplementasikan oleh masyarakat Sasak.

\section{Pengaruh Kawin Lari dalam Sosial Kemasyarakatan}

Sikap "heroik" (kepahlawanan) merupakan salah satu alasan mengapa tradisi melarikan (melaian) dipertahankan dalam perkawinan dengan kekuatan adat di Lombok. Sikap demikian, menurut masyarakat Lombok merupakan sesuatu yang mutlak diperlukan apabila berkeinginan untuk membina rumah tangga dengan calon mempelai perempuan yang sudah diidam-idamkan. Dari sisi spirit "heroisme" tersebut sesungguhnya memiliki relevansi yang sangat erat dengan ajaran Islam. Islam senantiasa mengajarkan agar dua pihak yang ingin menikah hendaklah didasari oleh perasaan yang kuat untuk saling memiliki. Hanya saja perasaan tersebut tidak harus ditunjukkan dengan cara melarikan gadis sebagai calon isteri. Bandingkan dengan beberapa ayat atau hadits yang berkaitan dengan anjuran menikah. Dalam sebuah hadits disebutkan bahwa: "Manistathấa min kum al-bấat fa al-yatazawwaj" (Barang siapa yang telah mampu untuk menunai-kan nafkah kepada calon isterinya, maka hendaklah menikah). ${ }^{13}$ Mampu di sini diartikan mampu lahir maupun bathin, maka hendaklah mengajak calon isterinya menikah dengan cara yang diajarkan oleh Islam, yakni calon mempelai perempuan). Dalam QS. al-Nisâ (4): 4 disebutkan bahwa: "Berikanlah maskawin (mahar) kepada wanita (yang kamu nikahi) sebagai pemberian dengan penuh kerelaan." Ayat ini dapat pula dianggap sebagai tanda kesiapan seorang calon suami untuk menikahi seorang perempuan. Sekali lagi kesiapan atau keberanian untuk menikah daiam Islam harus dilakukan dengan sikap yang mencerminkan kesiapan mental maupun material, bukan sikap berani melarikan

${ }^{13}$ Ibn Rusyd, Bidâyah al-Mujtahid Nihâyat al-Muqtashid (Semarang: Usaha Keluarga, tt.), Jilid II, hlm. 2 
anak perempuan orang lain hanya karena merasa mampu melarikan perempuan tanpa sepengetahuan keluarganya.Tradisi adat Sasak Lombok ini sebenarnya sudah banyak yang paralel dengan ajaran Islam, seperti soal pisuke dan nyongkolan. Pisuke sesuai dengan namanya tidak boleh ada unsur pemaksaan, tetapi harus ada kerelaan keluarga kedua belah pihak. Demikian juga, acara nyongkolan merupakan sarana pengumuman dan silaturrahmi sebagaimana yang dianjurkan oleh Nabi Muhammad saw. Hanya saja dalam kasus tertentu terjadi penyelewengan oleh oknum pada acara nyongkolan yang menyebabkan terjadinya perkelaian, mabuk-mabukan dengan minuman keras dan meninggalkan shalat, maka perilaku inilah yang perlu dihindari dalam praktik nyongkolan.

Singkatnya, orang Sasak lah yang banyak melanggar aturan/adat Sasak itu sendiri. Hal ini bisa dilihat dari substansi buku yang ditulis oleh Gde Suparman. ${ }^{14}$ Saat ini ada beberapa praktik adat yang telah mengalami metamorfosa dan perubahan paradigma di masyarakat Sasak tentang perspektif merari' ini setelah mendalami ajaran agama Islam dan fenomena perkawinan adat lain di Indonesia seperti yang terjadi di Jawa dan Pulau Sumbawa. Perubahan ini memang tidak bisa secara sekaligus, tetapi secara bertahap, dan dimulai oleh warga Sasak yang berpendidikan dan memiliki pengalaman di daerah lain. Dalam banyak aspek (ranah) kehidupan. Ternyata perempuan Sasak masih sangat marginal (inferior), sementara kaum laki-lakinya sangat superior. Marginalisasi perempuan dan superioritas laki-laki memang merupakan persoalan lama dan termasuk bagian dari peninggalan sejarah masa lalu. Sejak lahir perempuan Sasak mulai disubordinatkan sebagai orang yang disiapkan menjadi isteri calon suaminya kelak dengan anggapan "ja'ne lalo/ja'ne tebait si' semamenne" (suatu saat akan meninggalkan orang tua diambil dan dimiliki suaminya). Sementara, kelahiran seorang anak laki-laki pertama biasanya lebih disukai dan dikenal dengan istilah anak prangge (anak pewaris tahta orang tuanya). ${ }^{15}$

14 Gde Suparman Dulang, Perkawinan (Mataram: Lembaga Pembakuan dan PenyebaranAdat Sasak, 1995) dan Idem, Titi Tata Adat Perkawinan Sasak, Kepembayunan Lan Candrasengkala (Mataram: Lembaga Pembukuan dan Penyebaran Adat Sasak Mataram Lombok, 1988).

${ }^{15}$ Ani Wafiroh, "Pemberdayaan Wanita Sasak", Tengaji, Majalah Berita dan Dakwah, edisi 12 Maret-9 April 2005 
Begitu juga tradisi perkawinan Sasak, seakan-akan memosisikan perempuan sebagai barang dagangan. Hal ini terlihat dari awal proses perkawinan, yaitu dengan dilarikannya seorang perempuan yang dilanjutkan dengan adanya tawar menawar uang pisuke (jaminan).

Menurut penuturan Muslihun Muslim. ${ }^{16}$ Terdapat 9 bentuk superioritas suami sebagai dampak dari tradisi perkawinan adat Sasak (merari') sebagai berikut: (1) terjadinya perilaku atau sikap yang otoriter oleh suami dalam menentukan keputusan keluarga; (2) terbaginya pekerjaan domestik hanya bagi isteri dan dianggap tabu jika lelaki (suami) Sasak mengerjakan tugas-tugas domestik; (3) perempuan karier juga tetap diharuskan dapat mengerjakan tugas domestik di samping tugas atau pekerjaannya di luar rumah dalam memenuhi ekonomi keluarga (double burden/peran ganda); (4) terjadinya praktik kawin-cerai yang sangat akut dan dalam kuantitas yang cukup besar di Lombok; (5) terjadinya peluang berpoligami yang lebih besar bagi laki-laki (suami) Sasak dibandingkan lelaki (suami) dari etnis lain; (6) kalau terjadi perkawinan lelaki jajar karang dengan perempuan bangsawan, anaknya tidak boleh menggunakan gelar kebangsawanan (mengikuti garis ayah), tetapi jika terjadi sebaliknya, anak berhak menyandang gelar kebangsawanan ayahnya; (7) nilai perkawinan menjadi ternodai jika dikaitkan dengan pelunasan uang pisuke; (8) kalau terjadi perceraian, maka isterilah yang biasanya menyingkir dari rumah tanpa menikmati nafkah

\footnotetext{
${ }^{16}$ Muslihun Muslim dan Muhammad Taisir, Tradisi Merari': Analisis Hukum Islam dan Gender terhadap Adat Perkawinan Sasak (Yogyakarta: Kurnia Kalam Semesta, 2009), hlm. 130-131. Kondisi ini telah menempatkan kaum perempuan bangsawan Sasak dalam posisi yang tidak menguntungkan, sehingga melahirkan pelbagai bentuk ketidakadilan gender (gender inequalities) yang termanifestasi antara lain dalam bentuk marginalisasi dan subordinasi. Bias gender dalam stratifikasi perempuan bangsawan Sasak ini menyebabkan mereka memiliki akses yang terbatas dalam menentukan jodohnya, sehingga banyak perempuan bangsawan yang terlambat kawin, bahkan tidak kawin sama sekali karena aturan dan pranata adat yang ketat dan rigit. Namun apabila ia nekat kawin dengan laki-laki dengan strata yang lebih rendah, maka ia akan menerima konsekuensi sanksi adat "dibuang" yang menempatkannya pada posisi marjinal dan subordinatif. Lihat Muhammad Harfin Zuhdi, Bias Gender Stratifikasi Perempuan Bangsawan Sasak dalam Perkawinan Masyarakat Lombok Nusa Tenggara Barat (Penelitian Individual Kompetitif Kementerian Agama RI, 2010)
} 
selama 'iddah, kecuali dalam perkawinan nyerah hukum atau nyerah mayung sebungkul; (9) jarang dikenal ada pembagian harta bersama, harta biasanya diidentikkan sebagai harta ayah (suami) jika ada harta warisan, sehingga betapa banyak perempuan (mantan isteri) di Sasak yang hidup dari belaian nafkah anaknya karena dianggap sudah tidak memiliki kekayaan lagi.

\section{Kawin Lari dalam Perspektif Kajian Hukum Islam}

Kawin lari merupakan suatu tradisi yang sudah dijalankan oleh warga Lombok sejak zaman leluhur mereka hingga saat ini. Kawin lari dalam adat sasak disebut dengan istilah merari'. Merari' ini merupakan adat asli suku Sasak yang masih mentradisi di Lombok. Sebagaimana yang telah penulis paparkan di atas bahwa merari' ialah membawa lari calon pengantin perempuan oleh calon pengantin lelaki ke tempat keluarga si lelaki untuk disembunyikan dengan tujuan supaya dapat dinikahi dan dijadikan istri.

Sebelum menetapkan status hukum kawin lari ini, penulis akan menganalisis tahapan demi tahapan dalam proses kawin lari tersebut dengan berpedoman kepada maqâshid al-syarî'ah. Sebagaimana yang telah penulis paparkan pada pembahasan sebelumnya bahwa proses kawin lari ada beberapa tahapan.

Pertama, midang. Tradisi midang ini sebenarnya bukan asli adat sasak, tetapi sering kali dilakukan oleh para pemuda yang sedang pacaran. Midang adalah salah satu cara untuk melakukan pertemuan dan berbicara langsung dengan pacar. Kalau midang ini bertujuan untuk mempererat silaturrahmi, saling menasihati, dan tidak hanya duduk berdua dengan pacarnya, tetapi orang tua si pacar juga ikut duduk bersama, maka menurut penulis, tidak ada masalah dan bolehboleh saja. Sama halnya dengan orang-orang yang melakukan jual beli, sewa-menyewa, belajar, berdiskusi, musyawarah, dan kegiatan mu'amalah lainnya.

Akan tetapi, tidaklah demikian kenyataan yang terjadi di lapangan. Para pemuda memanfaatkan momen midang ini untuk melepas rindu dengan pacarnya, duduk berduaan di rumah si perempuan, saling memuji, merayu, dan menggoda sehingga sering kali menimbulkan syahwat bahkan melakukan hal-hal yang melanggar syarî'ah, seperti saling menyentuh, berpegangan tangan, saling meraba dan seterusnya. Bila hal ini terjadi maka tradisi midang seperti ini jelas telah melanggar syarî'ah. Sebagaimana firman Allah 


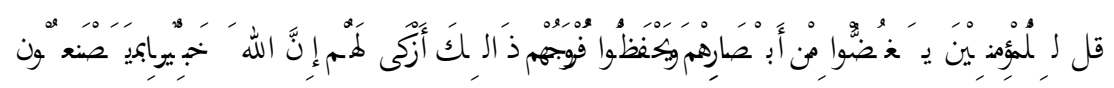

"Katakanlah kepada orang laki-laki yang beriman: "Hendaklah mereka menahan pandanganya, dan memelihara kemaluannya; yang demikian itu adalah lebih suci bagi mereka, Sesungguhnya Allah Maha mengetahui apa yang mereka perbuat". 17

Sebenarnya tidak hanya tradisi midang seperti ini yang dilarang oleh syarî'ah, tetapi berpacaran itu sendiri sudah tidak sesuai dengan syarî'ah. Karena orang yang berpacaran sekarang ini tidak bisa terhindar dari berdua-duaan di tempat yang sunyi, di rumah, sekolah, kampus, kos, pantai, taman, di mall, dan sebagainya. Tidak hanya itu, terkadang anak muda zaman sekarang, merasa tidak puas bila bertemu dan mengobrol saja. Mereka sering kali memanfaatkan masa pacaran ini untuk saling berpengangan tangan, berpelukan bahkan saling berciuman. Ada yang mengatakan: "Rasanya kurang afdhal kalau kita berpacaran tapi belum merasakan ciuman atau berpelukan." Ada juga yang mengatakan: "Rugi banget kalau kita punya pacar tapi belum pernah menciumnya." Realitas sekarang ini, orang yang berpacaran menganggap bahwa berpelukan atau pun berciuman itu adalah hal yang biasa, bahkan mereka tidak segansegan untuk tidur bareng dan melakukan hubungan intim dengan pacarnya. Inilah alasan syarî́ah tidak membolehkan berpacaran, karena tidak hanya mendekati zina yang jelas-jelas merupakan larangan Allah sebagaimana firman-Nya:

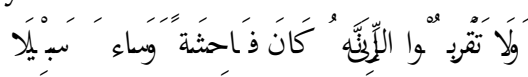

"Dan janganlah kamu mendekati zina; Sesungguhnya zina itu adalah suatu perbuatan yang keji. dan suatu jalan yang buruk."18

Bahkan pacaran sering kali menjerumuskan orang ke dalam perzinahan. Telah dimaklumi bahwa zina itu merupakan salah satu dosa besar yang wajib dihindari. Bila seseorang terjerumus ke dalam perzinahan, maka dalam perspektif maqâshid al-syarî'ah, dia harus dirajam di hadapan orang-orang mu'min supaya ada efek jera dan

17 Departemen Agama RI, al-Qur`an dan Terjemahnya (Jakarta: PT. Bumi Restu, 1994)

${ }^{18}$ Ibid. 
sebagai peringatan bagi orang-orang yang menyaksikan. Sebagaimana firman Allah:

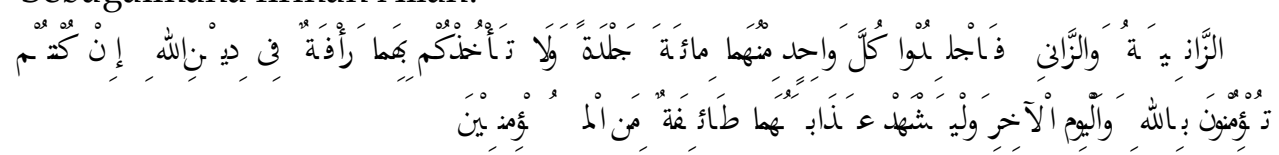

"Perempuan yang berzina dan laki-laki yang berzina, Maka deralah tiap-tiap seorang dari keduanya seratus kali dera, dan janganlah belas kasihan kepada keduanya mencegah kamu untuk (menjalankan) agama Allah, jika kamu beriman kepada Allah, dan hari akhirat, dan hendaklah (pelaksanaan) hukuman mereka disaksikan oleh sekumpulan orangorang yang beriman. ${ }^{19}$

Tahap kedua dari proses kawin lari adalah memaling (mencuri). Inilah inti dari adat kawin lari. Karena kawin lari itu sendiri di dalam masyarakat Lombok lebih populer dengan sebutan memaling. Pengertian memaling (mencuri) telah penulis jelaskan secara panjang lebar pada sub bab sebelumnya. Pada intinya, memaling adalah proses membawa lari seorang gadis tanpa sepengetahuan orang tuanya dengan tujuan untuk segera dinikahi.

Bila dilihat secara sekilas, istilah memaling (mencuri), maka secara spontan orang akan mengatakan bahwa perbuatan itu apapun bentuk dan motifnya tidak boleh dilakukan karena melanggar syarî'ah. Dan pelaku pencurian itu bisa dihukum potong tangan sebagaimana tercantum dalam QS. al-Mầidah: 38. Tetapi sebelum menghukumi suatu perbuatan, orang harus menelaah terlebih dahulu makna dan tujuan dari penggunaan suatu istilah. Seperti istilah memaling (mencuri) di sini berbeda dengan makna penggunaan kata mencuri pada umumnya. Pengertian mencuri secara umum adalah mengambil milik orang lain tanpa izin yang punya. Sedangkan mencuri (memaling) dalam hal ini mengandung pengertian membawa lari seorang gadis yang diduhului oleh suatu kesepakatan dan didasarkan perasaan suka sama suka, meskipun tidak seizin orang tua si gadis itu.

Memaling hanyalah suatu adat yang tidak menyimpang dari syarî'ah dan mengandung beberapa kemaslahatan, di antaranya ialah

${ }^{19}$ Ibid. 
memudahkan bagi pihak lelaki, meringankan beban baik pihak keluarga lelaki ataupun perempuan, prosesnya lebih cepat dari pada tunangan ataupun melamar. Menurut penulis, bila ditinjau dari segi hukum Islam, tradisi memaling ini sudah sesuai dengan maqâshid alsyarî'ah yaitu adanya kemaslahatan. Dalam hal ini kemaslahatannya tergolong dalam kategori mashlahah mursalah, bukan mashlahah $m u$ 'tabarah, karena tidak ada nash yang menganjurkannya, dan bukan pula mashlahah mulghah, karena tidak ada nash yang bertentangan dengan tradisi seperti ini.

Alasan lain kenapa penulis membolehkan tradisi memaling ini adalah karena tradisi ini sudah berkembang dan sudah dipraktikkan oleh masyarakat Lombok sejak zaman leluhur mereka. Bahkan, si pemuda sering kali merasa malu kalau si gadis minta supaya dia dilamar. Apalagi kalau si pemuda itu berasal dari keluarga yang kurang mampu. Karena memaling telah menjadi adat di Lombok, maka sebagian besar warga Lombok cenderung dan mengambil langkah ini untuk melangsungkan sebuah pernikahan.

Tahap selanjutnya adalah nyebo', beselabar, besejeti, dan kreme gubuq. Keempat tahapan ini murni adat Sasak, dan mungkin tidak terdapat pada suku lain di Indonesia. Ditinjau dari aspek pelaksanaannya, tidak ada yang bertentangan dengan syarî́ah. Sehingga tahapan-tahapan ini boleh dan sah-sah saja dilakukan oleh masyarakat Lombok. Karena ini berhubungan dengan mu'âmalah dan tidak ada kaitannya dengan ibadah. Sedangkan hukum dasar dari mu'amalah adalah boleh sebagaimana disebutkan dalam qấ'idah figh:

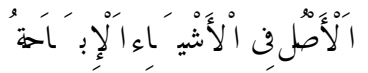

"Pada dasarnya hukum dari segala sesuatu (mu'amalah) itu adalah boleh." 20

Selanjutnya adalah tahap ngendeng weli (minta wali). Tahapan ini dilakukan beberapa jam sebelum dilangsungkannya akad nikah (bekawin). Tradisi ini jelas tidak mengandung unsur dosa dan pelanggaran. Karena setiap orang yang hendak melangsungkan akad nikah pasti meminta wali kepada orang tua atau wali dari si perempuan terlebih dahulu. Oleh karena itu, penulis menganggap

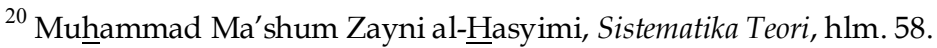


tidak perlu untuk mendatangkan dalil atau pun $q a^{\prime} i d a h$ yang membolehkan tradisi ngendeng weli ini karena sudah jelas hukumnya boleh bahkan wajib karena wali merupakan salah satu rukun nikah. ${ }^{21}$

Tahap berikutnya adalah bekawin (akad nikah). Bekawin ini merupakan inti dari sebuah pernikahan. Dengan cara apa pun orang melaksanakan pernikahan pasti akan melaksanakan proses bekawin ini. Bekawin bukan hanya sebagai adat tapi merupakan bagian dari syarî'ah. Sah atau tidaknya proses bekawin ini tidak ditentukan oleh adat atau tradisi, tetapi sudah diatur dalam syarî'ah mengenai rukun dan syaratnya. Bila ditinjau dari segi maqâshid al-syarî'ah, maka proses bekawin inilah yang menjadi inti dari semua proses pernikahan, baik dengan cara tunangan, melamar atau pun memaling.

Tahap selanjutnya adalah bekuade dan begawe bajang. Tradisi ini sebenarnya bukan asli adat Sasak, tetapi sudah menjadi tradisi di Sekarbela. Bekuade dan begawe bajang sebagaimana yang telah dijelaskan di depan adalah hampir sama dengan acara resepsi. Hanya saja bekuade/bagawe bajang ini hanya dihadiri oleh para pemuda yang merupakan teman dan sahabat si pengantin lelaki yang berasal dari kampung yang sama.

Tujuan dari bekuade/begawe bajang adalah untuk berbagi kebahagiaan dengan warga sekitar terutama kaum pemuda dengan menyiapkan berbagai sajian makanan, kemudian para tamu undangan memberikan amplop sebagai rasa persahabatan mereka dan rasa syukur terhadap kebahagiaan yang telah dirasakan oleh si pengantin. Bekuade/begawe bajang ini juga bertujuan sebagai motivasi supaya pemuda-pemuda yang belum menikah agar segera menyusul ke pelaminan.

Berdasarkan tujuannya ini, maka penulis berpendapat bahwa tradisi bekuade dan begawe bajang ini hukumnya boleh, karena tidak bertentangan dengan maqâshid al-syarî'ah, bahkan bisa jadi dianjurkan karena dapat memotivasi bagi para pemuda yang belum menikah supaya segera menikah agar terhindar dari perbuatan maksiat yang merupakan salah satu bagian pokok dari maqâshid al-syarî'ah yaitu hifzh al-nasl.

${ }^{21}$ Rukun nikah ada lima, yaitu: Shighah, pengantin lelaki, pengantin perempuan, wali, dan dua orang saksi. Lihat al-Habsyi, al-Sirâj al-Wahhâj 'alâ Matn al-Minhâj (Beirut: Dâr al-Fikr, 2004), hlm. 269. 
Selanjutnya adalah tahap selametan. Tradisi selametan ini sebenarnya telah ada di dalam Islam, yaitu biasa disebut dengan istilah walimah al-ursy. Jadi penulis tidak perlu menjelaskan argumentasi panjang lebar tentang kebolehan tradisi selametan ini karena sudah merupakan anjuran dari syarî'ah dan tidak bertentangan dengan maqâshid al-syarî'ah.

Berikutnya adalah sorong serah dan nyongkolan. Kedua tahapan ini telah penulis paparkan secara lengkap pada pembahasan sebelumnya. Inti dari kedua tradisi ini adalah acara perkenalan antar dua keluarga besar yaitu keluarga dari pengantin lelaki dan keluarga dari pengantin perempuan. Bila hal ini yang terjadi maka penulis cenderung mengatakan boleh, karena tradisi ini tidaklah bertentangan dengan syarî'ah dan mengandung suatu kemaslahatan yang merupakan inti dari maqâshid al-syarî'ah.

Namun, dalam pengamatan penulis, khususnya pada tradisi nyongkolan, sering kali ada orang yang tidak shalat 'Ashar pada waktunya alias meng-qadla' shalatnya, karena acara nyongkolan ini biasanya dilaksanakan sebelum shalat 'Ashar dan berakhir sekitar satu jam sebelum waktu Maghrib tiba. Sebenarnya, bukan acara nyongkolan itu yang menyebabkan mereka meng-qadla' shalat, tetapi kelalaian mereka lah yang menjadi faktor penyebabnya. Karena ada rentang waktu satu jam untuk melaksanakan shalat Ashar sebelum waktu maghrib tiba, tetapi mereka malah menghabiskan waktu untuk duduk-duduk santai dan melalaikan waktu shalat.

Apabila hal ini selalu terjadi dalam tradisi nyongkolan, maka penulis cenderung mengatakan bahwa nyongkolan itu adalah haram karena telah melanggar maqâshid al-syarî'ah yaitu hifzh al-dîn. Dalam qa'idah figh dikatakan:

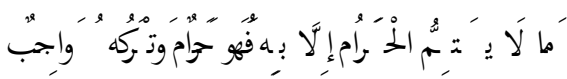

"Segala sesuatu yang tidak sempurna perbuatan haram kecuali dengannya, maka perbuatan itu haram dan meninggalkannya adalah wajib." 22

\footnotetext{
${ }^{22}$ Maktabah Syamilah, Talqîh al-Afhâm al-'Aliyyah bi Syarh al-Qawố'id al-Fiqhiyyah, Juz 3, hlm. 21.
} 
Qâ'idah ini berarti bahwa segala hal yang membawa (menjadi perantara) kepada perbuatan haram maka hukumnya adalah haram dan wajib ditinggalkan. Jadi, kalau tradisi nyongkolan ini selalu membawa kepada perbuatan yang dilarang syarî'ah, maka hukumnya haram, tetapi kalau tidak maka boleh.

Selanjutnya bila ditinjau dari substansinya, kawin lari sebenarnya hanya merupakan sebuah metode untuk melangsungkan pernikahan karena inti dari kawin lari adalah proses memaling. Selain itu, ada juga metode lain yang bisa digunakan seperti melamar dan tunangan. Meskipun metode kawin lari ini tidak pernah dijelaskan di dalam nash (al-Qur'an dan Hadits), tetapi bila ditinjau dari perspektif maqâshid al-syarî'ah, maka stutus hukum pernikahan dengan metode kawin lari ini tetap sah. Karena dalam kelangsungan akad nikahnya tetap memenuhi syarat dan rukun sebagaimana yang telah disyari'atkan Islam.

Bila dilihat secara universal, maka pernikahan dengan metode kawin lari ini hukumnya sah sama halnya dengan pernikahan melalui proses lamaran ataupun tunangan.

\section{Penutup}

Perkawinan ialah ikatan lahir batin antara seorang pria dengan seorang wanita sebagai suami istri untuk membentuk keluarga yang bahagia dan kekal berdasarkan Ketuhanan Yang Maha Esa. Ikatan perkawinan merupakan ikatan suci yang berdasarkan nilai-nilai ketuhanan untuk membentuk keluarga sakînah, mawaddah dan rahmah. Salah satu adat yang dipegang teguh oleh masyarakat Lombok adalah kawin lari. Dalam adat Sasak, pernikahan dengan cara kawin lari ini lebih populer disebut dengan merari'. Oleh karena itu, merari' dalam bahasa Indonesia disebut dengan istilah kawin lari. Secara terminologis, merari' mengandung dua arti. Pertama, lari atau melarikan. Ini adalah arti yang sebenarnya. Kedua, keseluruhan pelaksanaan perkawinan menurut adat Sasak. Bagi masyarkat Sasak, merari' berarti mempertahankan harga diri dan menggambarkan sikap kejantanan seorang pria Sasak, karena ia berhasil mengambil (melarikan) seorang gadis pujaan hatinya. Sementara pada isi lain, bagi orang tua gadis yang dilarikan juga cenderung enggan, kalau tidak dikatakan gengsi, untuk memberikan anaknya begitu saja jika diminta secara biasa (konvensional), karena mereka beranggapan 
bahwa anak gadisnya adalah sesuatu yang berharga, jika diminta secara biasa, maka dianggap seperti meminta barang yang tidak berharga. kawin lari sebenarnya hanya merupakan sebuah metode untuk melangsungkan pernikahan karena inti dari kawin lari adalah proses memaling. Selain itu, ada juga metode lain yang bisa digunakan seperti melamar dan tunangan. Meskipun metode kawin lari ini tidak pernah dijelaskan di dalam nash (al-Qur`an dan Hadits), tetapi bila ditinjau dari perspektif maqâshid al-syarî'ah, maka stutus hukum pernikahan dengan metode kawin lari ini tetap sah, karena dalam kelangsungan akad nikahnya tetap memenuhi syarat dan rukun sebagaimana yang telah disyari'atkan Islam.

\section{Daftar Pustaka:}

Anshary, M. MK, Hukum Perkawinan di Indonesia. Yogyakarta: Pustaka Pelajar, 2010.

Azmeh, Aziz al-. Islamic Law: Social and Historical Contexts. tp., 1988.

Bartholemew, John Ryan. Alif Lam Mim: Kearifan Masyarakat Sasak. Yogyakarta: Tiara Wacana, 2001.

Departemen Agama RI, al-Qur'an dan Terjemahnya. Jakarta: PT. Bumi Restu, 1994.

Dulang, Gde Suparman. Titi Tata Adat Perkawinan Sasak, Kepembayunan Lan Candrasengkala. Mataram: Lembaga Pembukuan dan Penyebaran Adat Sasak Mataram Lombok, 1988.

Dulang, Gde Suparman. Perkawinan. Mataram: Lembaga Pembakuan dan PenyebaranAdat Sasak, 1995.

Habsyi, al-. al-Sirâj al-Wahhâj 'alâ Matn al-Minhâj. Beirut: Dâr al-Fikr, 2004.

Maktabah Syamilah, Talqîh al-Afhâm al-'Aliyyah bi Syarh al-Qawấ'id alFiqhiyyah, Juz 3.

Muslim, Muslihun dan Taisir, Muhammad. Tradisi Merari': Analisis Hukum Islam dan Gender terhadap Adat Perkawinan Sasak. Yogyakarta: Kurnia Kalam Semesta, 2009.

Nuruddin, Amir dan Tarigan, Azhari Akmal. Hukum Perdata Islam di Indonesia. Jakarta: Kencana Prenada Media Group, 2006.

Rusyd, Ibn. Bidâyah al-Mujtahid Nihâyat al-Muqtashid. Semarang: Usaha Keluarga, tt. 
Salam, Solichin. Lombok Pulau Perawan: Sejaroh dan Masa Depannya. Jakarta: Kuning Mas, 1992.

Soekanto, Soejono. Pokok-Pokok Sosiologi Hukum. CV Rajawali: Jakarta: 1982.

Tibbi, Bassam. Islam and Cultutral Accommodation of Social Change. San Francisco: Westview Pres, 1991.

Tim Departemen Pendidikan dan Kebudayaan, Adat dan Upacara Perkawinan Daerah Nusa Tenggara Barat. Jakarta: Depdikbud, 1995.

Wafiroh, Ani. "Pemberdayaan Wanita Sasak", Tengaji, Majalah Berita dan Dakwah, edisi 12 Maret-9 April 2005

Yasin, M. Nur. "Kontekstualisasi Doktrin Tradisional di Tengah Modernisasi Hukum Nasional: Studi tentang Kawin Lari (Merari') di Pulau Lombok", Jurnal Istinbath, no. I vol. IV (Desember 2006)

Zakaria, Fath. Mozaik Budaya Orang Mataram. Mataram: Yayasan Sumurmas Al-Hamidy, 1998.

Zuhdi, Muhammad Harfin. Bias Gender Stratifikasi Perempuan Bangsawan Sasak dalam Perkawinan Masyarakat Lombok Nusa Tenggara Barat. Penelitian Individual Kompetitif Kementerian Agama RI, 2010.

Zuhdi, Muhammad Harfin. Parokilaitas Adat Islam Wetu Telu dalam Prosedur Perkawinan di Bayan Lombok. Tesis Program Pascasarjana UIN Jakarta, 2004.

Zuhdi, Muhammad Harfin. Tradisi Merari'; Akulturasi Islam dan Budaya Lokal, $\quad$ http://lombokbaratkab.go.id/tradisimerari\%E2\%80\%99-akulturasi-islam-dan-budaya-lokal.html/, diakses pada 29 April 2012. 